УДК 378.4

\title{
РОЛЬ ИННОВАЦИОННЫХ ТЕХНОЛОГИЙ В ФОРМИРОВАНИИ ПРОФЕССИОНАЛЬНЫХ КОМПЕТЕНЦИЙ
}

\author{
Ханина Елена Евгеньевна \\ студент \\ Федеральное государственное образовательное \\ учреждение высшего образования \\ «Тихоокеанский государственный медицинский университет» \\ Чагина Полина Александровна \\ студент \\ Федеральное государственное автономное \\ образовательное учреждение высшего образования \\ «Национальный исследовательский университет ИТМО» \\ Научные руководители: Турмова Екатерина Павловна \\ д.м.н., доцент \\ Чагина Евгения Александровна \\ к.м.н., доцент \\ Федеральное государственное образовательное \\ учреждение высшего образования \\ «Тихоокеанский государственный медицинский университет»
}

\begin{abstract}
Аннотация: В статье были рассмотрены вопросы возможности применения и использования инновационных технологий в образовательном процессе обучающихся, которые позволяют получать не только новые знания, но и развивают познавательную деятельность, переводят её на более высокие формы в учебном процессе. Преподавание теоретического материала на основе наглядных примеров является основополагающим методическим приёмом образовательной деятельности.
\end{abstract}

Ключевые слова: инновационные технологии, образовательные технологии, инновации, деловая игра, кейс-технологии. 


\title{
THE ROLE OF INNOVATIVE TECHNOLOGIES IN THE FORMATION OF PROFESSIONAL COMPETENCIES
}

\author{
Khanina Elena Evgenievna \\ Chagina Polina Aleksandrovna \\ Scientific adviser: Turmova Ekaterina Pavlovna \\ Chagina Evgenia Aleksandrovna
}

\begin{abstract}
The article discusses the possibility of applying and using innovative technologies in the educational process of students, which allow them to receive not only new knowledge, but also develop cognitive activity, which translates it to higher forms in the educational process. Teaching theoretical material based on visual examples is a fundamental methodological technique of educational activity.
\end{abstract}

Key words: innovative technologies, educational technologies, innovations, business game, case technologies.

В последние годы государство прилагает большие усилия для поднятия образования студентов вузов на качественно новый уровень. В современных условиях предъявляются высокие требования к уровню знаний, как фундаменту профессиональной и мировоззренческой подготовки [1]. Основная роль направлена не на простое формирование у обучающихся системы знаний, умений и навыков, а на набор базовых компетенций в интеллектуальной, коммуникационной, информационной и других сферах. Термин «компетенция» шире понятия знание или умение. Для него характерны следующие признаки: многофункциональность (овладение которых позволит решать проблемы повседневной, профессиональной и социальной жизни), интеллектуальное развитие (выработка собственной позиции, самооценка, критическое мышление), многомерность (умственные процессы, интеллектуальные умения), междисциплинарность. Цель освоения компетенций состоит в формировании умения эффективно решать профессиональные задачи.

Успешное освоение компетенций (согласно ФГОС $\mathrm{BO}$ 3++) затруднительно без применения инновационных методов обучения образовательных технологий. Для использования образовательных технологий дисциплины необходимы знания, умения и навыки, разные уровни сформированных при обучении, по основным образовательным программам высшего образования (специалитет) по специальности. 
В конечном итоге применение образовательных технологий помогают решать профессиональные задачи специалиста.

Целями применения образовательной технологии учебной дисциплины являются:

- повышение качества подготовки путём формирования творческого потенциала

- аналитического мышления, коммуникативных навыков

- способности к самообучению для повышения уровня сформированности компетенций

- личностного роста на протяжении всего периода обучения и в дальнейшей профессиональной деятельности

Использование образовательной технологии реализует следующие задачи:

- анализ проблемной ситуации

- аргументировано высказывать собственное мнение

- способность к самостоятельному обучению

- совершенствование практических навыков [2,с.206].

Инновационные образовательные технологии ориентируют на создание и использование таких форм организации учебной деятельности, при которых акцент делается на вынужденную активность обучающегося (не может не делать, не участвовать в действии) и на формирование системного мышления и способности генерировать идеи при решении творческих задач. К ним относятся технологии активного деятельностного типа, такие как анализ конкретных ситуаций.

Деятельность преподавателя в этой сфере должно быть направлено на оформление и предъявление информации таким образом, чтобы при минимуме затраченных психофизиологических ресурсов обучающегося был получен максимальный эффект усвоения. Преподавание теоретического материала на основе наглядных примеров является основополагающим методическим приёмом образовательной деятельности.

Деловая игра одна из имитационно-игровых форм активных методов обучения и полновесная часть учебного процесса. Её сценарий тщательно продумывается и готовится преподавательским составом. Наличие ролей предполагает игровую процедуру в работе с моделью, то есть общение обучаемых между собой и с преподавателем (модератором) в процессе имитации. Деловая игра представляет собой специфический способ управления учебно-познавательной деятельностью. С точки зрения профессиональной 
деятельности ситуация - это совокупность взаимосвязанных фактов, явлений и проблем, характеризующих конкретный период или событие в деятельности организации, требующих от её руководителей соответствующих решений, распоряжений и других активных действий. Анализ конкретной ситуации - это глубокое и детальное исследование реальной или искусственной обстановки, выполняемое для того, чтобы выявить её характерные свойства. Этот метод развивает аналитическое мышление обучающихся, формирует системный подход к решению проблемы, позволяет выделять варианты правильных и ошибочных решений, выбирать критерии нахождения оптимального решения, учиться устанавливать деловые и профессиональные контакты, принимать коллективные решения, устранять конфликты [3,c.51]. Учебные ситуации как разновидность практических заданий лучше всего помогают формировать профессиональную компетенцию. Они содержат проблемную ситуацию, способствуют развитию способностей анализировать проблемную ситуацию, формированию способности к самостоятельному обучению и творческому подходу при решении профессиональных задач.

На сегодня также актуальным методом в педагогической практике остаётся кейс-задача. Выполнение кейс-задачи состоит из индивидуального этапа (по пороговому, продвинутому и высокому дескрипторам) и группового этапа. Обучающиеся, ознакомившись с описанием задачи, самостоятельно анализируют определённую ситуацию и представляют свои способы её решения, а затем оценивают альтернативные мнения в дискуссии с другими обучающимися.

Цели кейс-задачи: сформировать умение решать профессиональные задачи на основе теоретического анализа данных материалов дисциплины.

Кейс-технология как метод обучения и активизации учебного процесса ориентирован на решение следующих задач:

- овладеть навыками и приёмами всестороннего анализа ситуаций из сферы профессиональной деятельности

- отработать умение востребовать дополнительную информацию, необходимую для уточнения исходной ситуации

- приобрести навыки применения теоретических знаний для решения практических проблем

- развить навыки принятия решений в ситуации неопределённости

- приобрести навыки ясного и точного изложения собственной точки зрения в устной или письменной форме 
- выработать умение осуществлять презентацию, то есть убедительно преподносить, обосновывать и защищать свою точку зрения

- отработать навыки конструктивного критического оценивания точки зрения других

- научиться самостоятельно, принимать решения на основе группового анализа ситуации

Это способствует успешному и качественному овладению общепрофессиональными и профессиональными компетенциями обучающимися.

Виды кейсов:

- иллюстрирующие проблему, концепцию или решение в целом

- обучающие анализу и оценке ситуации

- обучающие решению проблемы и принятию решений, выполняющие функцию формирования у будущего специалиста профессиональных умений и развития оперативного мышления

Эффективность внедрения инновационных технологий в учебный процесс заключается в:

- повышении качества знаний при проведении аттестационнопедагогических измерений

- повышении уровня сформированности профессиональных компетенций

- предпочтении использования инновационной образовательной технологии традиционным методам обучения при проведении анонимных опросов

- повышении степени удовлетворённости обучающихся и профессорскопреподавательского состава качеством образования при использовании образовательной технологии (на $60 \%$ )

- возможность использования образовательной технологии дисциплинарного и междисциплинарного контроля в преподавании разных дисциплин основных и дополнительных образовательных программ

Делая вывод, что суть обучения с применением инновационных образовательных технологий состоит в том, что учебный процесс организован таким образом, когда практически все обучающиеся оказываются вовлечёнными в процесс обучения. Такая деятельность активизирует познавательную сферу, переводит её на более высокие формы кооперации и сотрудничества. Совершенствование и внедрение инновационных методов обучения позволяют оптимизировать образовательный процесс. 


\section{Список литературы}

1. Гакова Е.В. Игровые ситуации как условия формирования креативных компетенций студентов ВУЗа //Современные проблемы науки и образования. 2015. - № 1-1.; URL: http://science-education.ru/ru/article/view?id=17785 (дата обращения: 27.05.2021).

2. Орлянская Т.Я., Володичева Т.Б., Актушина Г.А. Использование элементов деловых игр в преподавании дисциплины «Основы медицинской генетики» как способ формирования основ клинического мышления у будущих врачей. /Современные наукоемкие технологии. - 2019. - № 7. - С. 205-209.

3. Демченко С.А. Кейс как инновационный метод обучения в вузе // Современная наука: тенденции развития. - 2016. - № 12. - С. 50-53.

(C) Е.Е. Ханина, П.А. Чагина, Е.П. Турмова, Е.А. Чагина, 2021 